\title{
CSNK1D wt Allele
}

National Cancer Institute

\section{Source}

National Cancer Institute. CSNK1D wt Allele. NCI Thesaurus. Code C125589.

Human CSNK1D wild-type allele is located in the vicinity of $17 q 25$ and is approximately 35 $\mathrm{kb}$ in length. This allele, which encodes casein kinase I isoform delta protein, plays a role in protein phosphorylation, cellular growth and cellular survival. Mutation of the gene is associated with familial advanced sleep phase syndrome-2. 